\title{
Lypsykarjarakennusten painovoimaiset ilmanvaihtoratkaisut
}

\author{
Tapani Kivinen $^{1)}$, Ismo Heimonen ${ }^{2)}$ ja Jorma Heikkinen ${ }^{2)}$ \\ ${ }^{1)}$ MTT Kotieläintuotannon tutkimus, Vakolantie 55,03400Vihti, tapani.kivinen@mtt.fi \\ ${ }^{2)}$ VTT, PL 1000,02044VTT, etunimi.sukunimi@vtt.fi
}

\section{Tiivistelmä}

Painovoimaisuus on ollut kotieläinrakennusten ainoa ilmanvaihtotekniikka historian pitkässä kaaressa. Koneellinen ilmanvaihto on ollut käytössä noin 1960-luvulta alkaen. Painovoimaisen tekniikan ero koneelliseen ilmanvaihtoon on siinä, että ilmaa ei siirretä koneellisesti puhaltimien avulla sisään ja/tai ulos. Painovoimainen ilmanvaihto nousi uudelleen esiin kylmäpihattojen myötä 1990-luvulla, mutta jäi kuitenkin marginaaliin. Painovoimaisuus merkitsee kuitenkin merkittävää energiasäästöä, koska puhaltimia ei tarvita. 2004 Suomeen asennettiin ensimmäinen verhoseinä lypsykarjarakennukseen. Verhoseinäisiä pihattoja lasketaan 2011 tilanteessa olevan jo noin $150 \mathrm{kpl}$. Verhoja, niiden mekanismeja samoin kuin poistoluukkuja ja hormeja on markkinoilla jo useita malleja. Ilmamäärien säätötavat ovat kehittyneet. Myös rakennuksissa on tapahtunut kehitystä kylmäpihatoista viileäpihatoiksi, joissa kattorakenteet on lämpöeristetty eristekerros ja sisäkatot nousevat ulkokaton suuntaisesti. Ilman luontevat kulkureitit pääsevät toteutumaan.

Verhoseinän toimivuutta on aikaisemmin tutkittu kattavalla koejärjestelyllä 2005-2006. Tuolloin tarkastelussa oli 3 verhoseinäpihattoa Etelä-Suomen alueella samalla kun Suomessa oli arviolta 20 verhoseinäkohdetta. Uusi verhoseinätutkimus - lypsykarjarakennusten kevennetyt ilmanvaihtoratkaisut - on porautunut järjestelmien teknisiin yksityiskohtiin sekä mitannut koneellisesta painovoimaiseksi muutetun pihaton olosuhteita ilmanvaihtoteknistä laskentaa varten. Mittauksella on selvitetty, missä määrin ikkunat poistamalla ja hormeja lisäämällä on saavutettu riittävä ilmanvaihtokapasiteetti.

Tutkimuksessa selvitettiin pakkaskauden 2009/2010 sekä kesän 2010 tilanteita. Talven 20092010 pakkaskaudella pihaton sisäolosuhteissa oli todettavissa suhteellisen kosteuden nousua, mikä johti sumun ilmenemiseen ja pintojen kostumiseen kondenssin ansiosta. Näistä huolimatta pihaton ilmanlaatua arvioitiin hyväksi. Verhon ja kennolevyn pintojen jäätymistä esiintyi yleisesti. Tuulisuuden koettiin vaikuttavan ilmanvaihtoon ja erityisesti kylmän tunteeseen. Maitotuotoksissa ei havaittu juurikaan alenemia. Kesäkauden 2010 hellejaksoilla pihaton sisälämpötilan nousu koettiin yleisesti haitalliseksi ja se lämpö vaikutti myös lehmien maitotuotokseen pienentävästi. Sisätuuletusta tehostettiin noin puolessa kohteista lisäpuhaltimilla. Ilman vaihtuvuuteen vaikutti kuitenkin eniten tuulisuus. Lämpö ja tuuli aiheuttivat myös lantakäytävien kuivumista, mikä johti niiden liukkauteen. Kaikkiaan pihaton sisälämpötila oli pääosin alempi kuin ulkolämpötila, mikä näkyi lehmien halukkuutena etsiytyä päivällä laitumelta pihattoon. Sisäilman laatu koettiin $90 \%$ :sti hyväksi.

Ilmanvaihdon määrään ja laatuun oltiin yleisesti tyytyväisiä, huonoa ilmanvaihtoa ei raportoinut kukaan kesällä eikä talvella. Eläinterveyden selvää parantumista raportoi $40 \%$ ja lievää parantumista noin $40 \%$ vastaajista. Tämän katsottiin johtuneen pääosin ilmanvaihdon laadun paranemisesta. Sorkkaterveys oli parantunut selvästi tai hieman noin $38 \%$ :lla kohteista. Lehmien maitotuotos oli lisääntynyt selvästi tai hieman liki $60 \%$ :ssa tiloista. Työntekijöiden työkuorma oli vähentynyt selvästi tai hieman noin $70 \%$ :lla ja samalla työviihtyvyys oli kasvanut noin $75 \%$ :1la. Tämä voi olla seurausta kahdesta seikasta: sisäilman laadun paranemisesta sekä pihattomelun (koneellisen ilmanvaihdon melu) radikaalista vähenemisestä aikaisempaan kotieläinrakennukseen verrattuna.

Lopuksi vastaajilta kysyttiin heidän yleistä tyytyväisyyttä valittuun ilmanvaihtoratkaisuun ja sen toimivuuteen. 97,8 \% oli täysin tyytyväinen valintaansa, 2,17\% ei osannut muodostaa mielipidettä, ja kukaan ei ollut tyytymätön. 


\section{Johdanto}

Tutkimuksessa tehtiin haastattelu, joka kohdistettiin kaikille 150 verhoseinäisiin pihattoihin investoineille maitotilallisille. Haastattelu tehtiin web-työkalun avulla ja vastauksia saatiin $50 \mathrm{kpl}$, vastausprosentti oli siten noin $30 \%$. Kyselyn pääkohtina olivat tekniset ratkaisut sekä painovoimaisen ilmanvaihdon vaikutukset eläinterveyteen, työntekijöiden työolosuhteisin ja työtyytyväisyyteen sekä pihaton olosuhteisin äärioloissa talven kylmä- ja kesän hellejaksoilla.

\section{Aineisto ja menetelmät}

Kyselytutkimuksen haastatteluosio oli jaoteltu aihealueittain seuraavasti:

1. kokemukset painovoimaisen ilmanvaihdon toimivuudesta

2. mitä tekisin toisin

3. ilmanvaihdon tekniset kehitystarpeet

4. tilan tiedot

5. rakennuksen mitat ja ilmanvaihdon toiminnan kuvaus

6. ilmanvaihdon tekniset ratkaisut ja investoinnit

Kyselyissä paneuduttiin talven 2009/2010 ja kesän 2010 äärisääolosuhteiden vaikutuksiin eläinten käyttäytymiseen sekä myös ihmisten työhyvinvointikysymyksiin ilmanvaihdon näkökulmasta. Rakennuksen mittatiedoilla oli mahdollista karkealla tasolla laskea ilmanvaihdon mitoituksellisia likiarvoja ja siten vertailla eri kohteita tosiinsa. Kyselytulokset täytettiin verkossa ja tulokset tallentuivat suoraan web-palvelutuottajan tietokantaan, josta tuloksia saattoi ajaa tilastollisina tarkasteluina eri muuttujien suhteen.

\section{Tulokset ja tulosten tarkastelu}

Kaikki vastaajat olivat maitotiloja. Joukossa ei ollut lihakarjarakennuksia, vaikka niihinkin verhoseiniä on asennettu. Noin $80 \%$ oli uudisrakennuksia ja loput laajennuksia tai peruskorjauksia. Rakennukset olivat olleet pääosin vain 1 - 2 vuotta käytössä. Vanhimmista verhoseinistä oli enintään 6 vuoden käyttökokemukset. Rakennuksista noin puolet sijaitsi avoimella pellolla, mikä edesauttaa painovoimaisuuden toiminnassa. Kolmasosa sijaitsi pellon ja metsän rajapinnassa ja muutama kohde keskellä metsää. Rakennuksen suuntaus vallitseviin tuuliin nähden jakautui $50 \%$ pohjoiseteläsuuntaan ja $50 \%$ itä-länsisuuntaan. Pihatoista hieman yli puolet oli varustettu rakopalkkilattialla ja alle puolet kiinteällä lantakäytävällä.

Painovoimaisen ilmanvaihtoratkaisun suunnittelijoissa ei ollut yhtään iv-ammattilaista. Ratkaisujen suunnittelijana ja mitoittajana oli toiminut pää- tai rakennussuunnittelija tai sitten laitetoimittaja tai laitemyyjä.

Ilman tulopuolella $66 \%: 1 l a$ oli käytössä verhoja ja $31 \%: 1 l a$ alas liukuvia kennolevyjä. $14 \%: 1 l a$ oli sekä verhoja että kennolevyjä. Yhdistelmätapauksessa kennolevyjä esiintyi yleisesti lypsyasemassa tai vasikkatilojen yhteydessä. Ilman poistopuolella avautuva tai kokonaan avonainen yhtenäinen harja oli $19 \%$ :ssa pihatoista ja hormipoisto $75 \%$ :lla. Lopuilla $6 \%$ :lla oli jokin muu poistoaukkoratkaisu. Poistohormeista $64 \%$ oli neliskanttisia ja $17 \%$ pyöreitä hormeja. Ilmanvaihdon säätö perustui 80 $\%$ :sti manuaalisuuteen ja automatiikkaohjaus oli vain $20 \%$ :lla kohteista. Ilman virtausta poistoaukossa pystyttiin säätämään liki $91 \%$ :ssa kohteita. Näin olleen valtaosa kohteita oli sellaisia jossa ilmamääriä voidaan säätää sekä tulo- että poistopuolella.

Kylmimpinä talvipäivinä pihatoissa käytettiin lisälämmitystä. $20 \%$ ssa kohteita oli kiinteä lisälämmitys, mikä toteutui lähinnä lypsyaseman lattialämmityksenä. Lantakäytävien lämmityksiä ei esiintynyt. Noin 40 \%:lla oli siirrettävä lyhytaikainen lisälämmitin, esimerkiksi öljypoltin tai vastaava. Lisälämmityksen käyttö oli vahvasti sidoksissa pihaton täyttöasteeseen. Vajaatäyttöisiä jouduttiin lisälämmittämään täysiä pihattoja huomattavasti enemmän. Vastaavasti kesä ylilämpöä torjuttiin vaakasuuntaan toimivilla puhaltaimilla10 \%:ssa ja iso helikopterituuletin $10 \%$ :ssa kohteista. Muuta kesäajan viilennystä ei ollut ellei sellaiseksi lueta lämpöeristettyä rakennusta itsessään, joka suojaa lehmiä auringon paahteelta. 
Talven 2009-2010 pakkaskaudella pihaton sisälämpötila ei laskenut 0 alapuolelle kertaakaan 54 $\%$ :ssa pihatoista. Parina päivänä se laski nollan alapuolelle $16 \%$ :lla ja $30 \%$ :lla nollan alittuma kesti useita päiviä tai jopa viikkoja. Viimemainituissa oli vajaatäyttöisiä kohteita. Myös kohteiden maantieteellisen sijainnin kirjo vaikutti eripituisiin nollan alituksiin. Yleisesti ottaen $90 \%$ vastasi ilmanvaihdon toimineen hyvin tai erittäin hyvin pakkaskaudella 2009/2010. Huonoa ilmanvaihtoa ei raportoitu lainkaan.

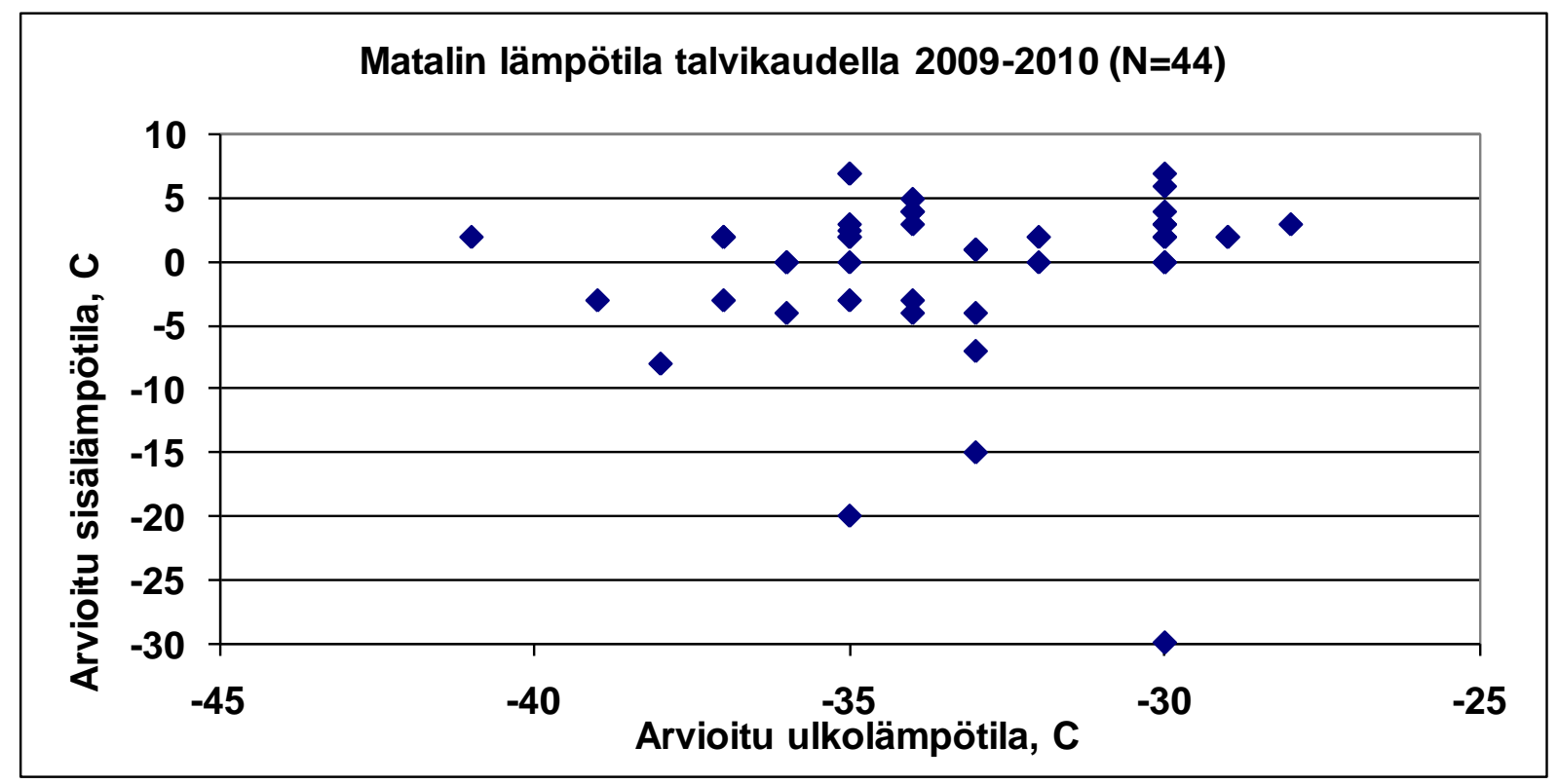

Kuva 1. Pihattojen sisä- ja ulkolämpötilajoen välinen riippuvuus talvella 2009-2010

Talven 2009-2010 pakkaskaudella pihaton sisäolosuhteissa oli todettavissa suhteellisen kosteuden nousua, mikä johti sumun ilmenemiseen ja pintojen kostumiseen kondenssin ansiosta. Näistä huolimatta pihaton ilmanlaatua arvioitiin hyväksi. Verhon ja kennolevyn pintojen jäätymistä esiintyi yleisesti. Tuulisuuden koettiin vaikuttavan ilmanvaihtoon ja erityisesti kylmän tunteeseen. Maitotuotoksissa ei havaittu juurikaan alenemia.

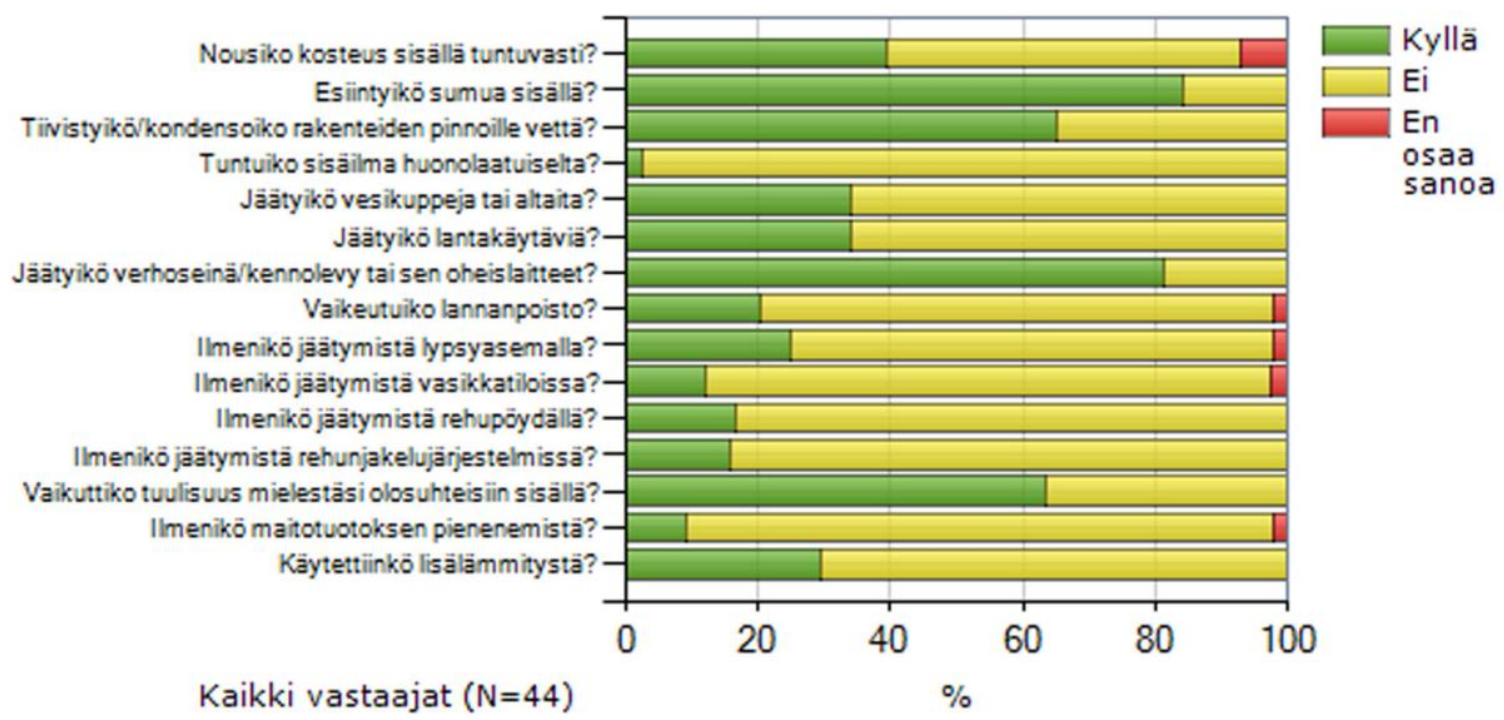

Kuva 2. Listaus pihaton sisällä tapahtuneista ilmiöistä talvella 2009-2010 
Kesäkauden 2010 hellejaksoilla pihaton sisälämpötila nousta yli $+35 \mathrm{C}^{\circ}$ asteen noin $30 \%$ :ssa tiloista ja ylitys kesti muutamasta päivästä viikkoon. Suurimmalla osalla (72 \%) lämpöeristetty katto piti sisälämpötilan alle $+35 \mathrm{C}^{\circ}$ asteessa.

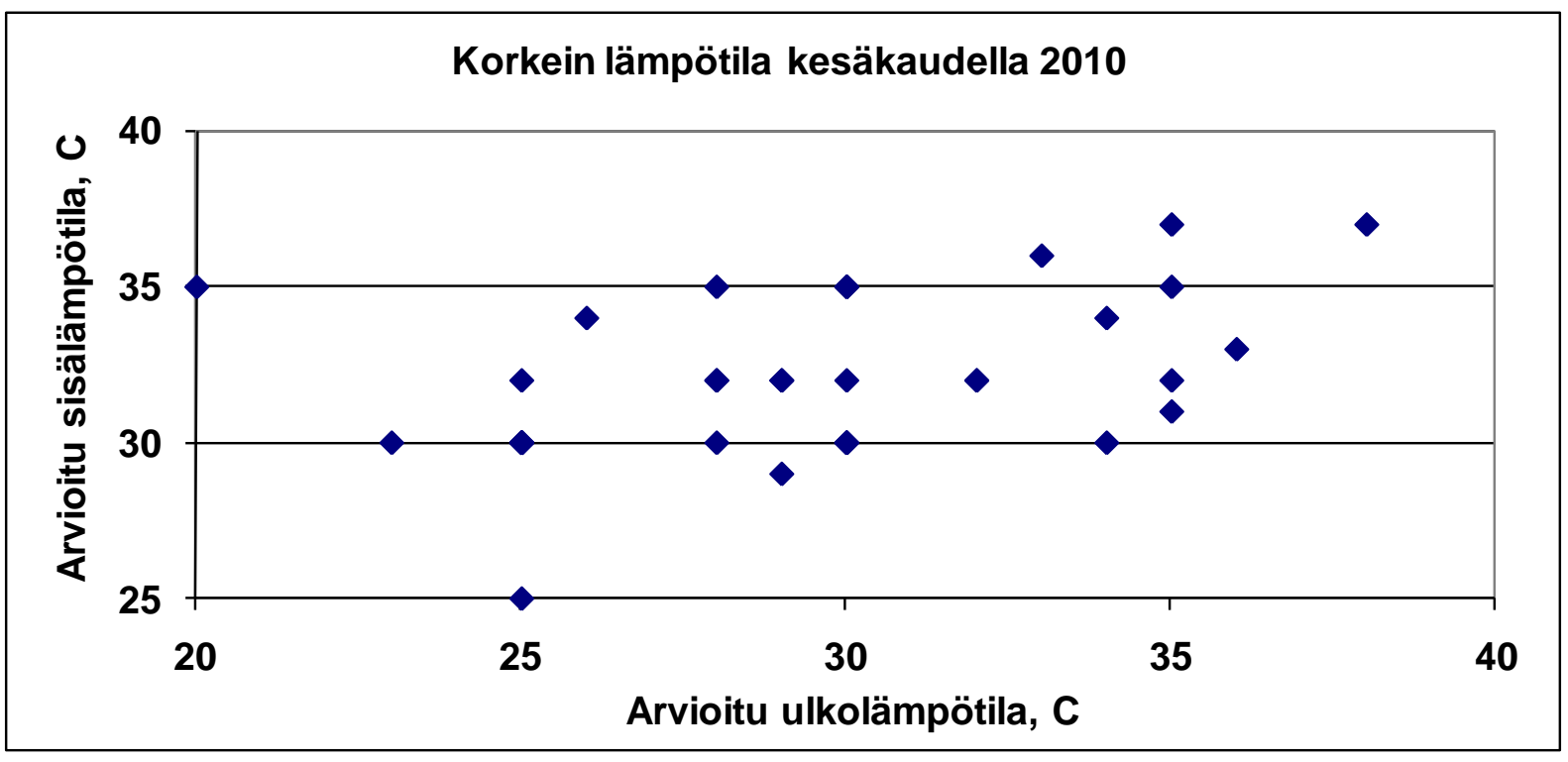

Kuva 3. Pihattojen sisä- ja ulkolämpötilojen välinen riippuvuus kesähelteillä 2010

Kesäkauden 2010 hellejaksoilla pihaton sisälämpötila nousu koettiin yleisesti haitalliseksi ja se lämpö vaikutti myös lehmien maitotuotoksen pienentävästi. Sisätuuletusta tehostettiin noin puolessa kohteista lisäpuhaltimilla. Ilman vaihtuvuuteen vaikutti kuitenkin eniten tuulisuus. Lämpö ja tuuli aiheutti myös lantakäytävien kuivumista, mikä johti niiden liukkauteen. Kaikkiaan pihaton sisälämpötila oli pääosin alempi kuin ulkolämpötila, mikä näkyi lehmien halukkuutena etsiytyä päivällä laitumelta pihattoon. Sisäilman laatu koettiin $90 \%$ :sti hyväksi.

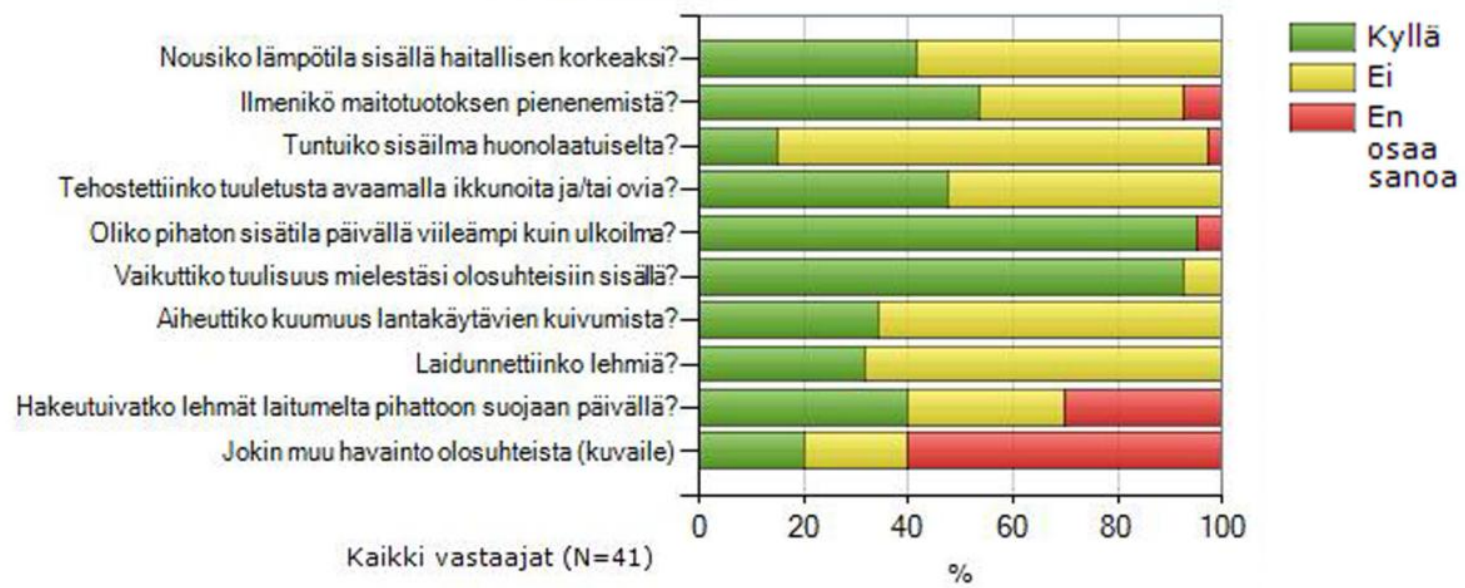

Kuva 4. Listaus pihaton sisällä tapahtuneista ilmiöistä kesällä 2010

\section{Johtopäätökset}

Web-kyselyn kohteena olleista noin 150 verhoseinäkohteesta 50 vastasi kyselyyn. Vastausprosenttia voidaan pitää olosuhteisiin nähden kohtuullisen hyvänä. Vastausten yhdensuuntaisuus oli merkille pantavaa, mm. kesä- ja talvilämpötilojen arvioinnit osuivat hämmästyttävän samoihin raja-arvoihin, mikä vahvistaa kokemusten olleen yhteneväisiä. Ilmanvaihdon määrään ja laatuun oltiin yleisesti tyytyväisiä, huonoa ilmanvaihtoa ei raportoinut kukaan kesällä eikä talvella. Eläinterveyden selvää 
parantumista raportoi $40 \%$ ja lievää parantumista noin $40 \%$ vastaajista. Tämän katsottiin johtuneen pääosin ilmanvaihdon laadun paranemisesta. Sorkkaterveys oli parantunut selvästi tai hieman noin 38 \%:lla kohteista. Lehmien maitotuotos oli lisääntynyt selvästi tai hieman liki $60 \%$ :ssa tiloista. Työntekijöiden työkuorma oli vähentynyt selvästi tai hieman noin $70 \%: 1 l a$ ja samalla työviihtyvyys oli kasvanut noin $75 \%$ :lla. Tämä voi olla seurausta kahdesta seikasta: sisäilman laadun paranemisesta sekä pihattomelun (koneellisen ilmanvaihdon melu) radikaalista vähenemisestä aikaisempaan kotieläinrakennukseen verrattuna.

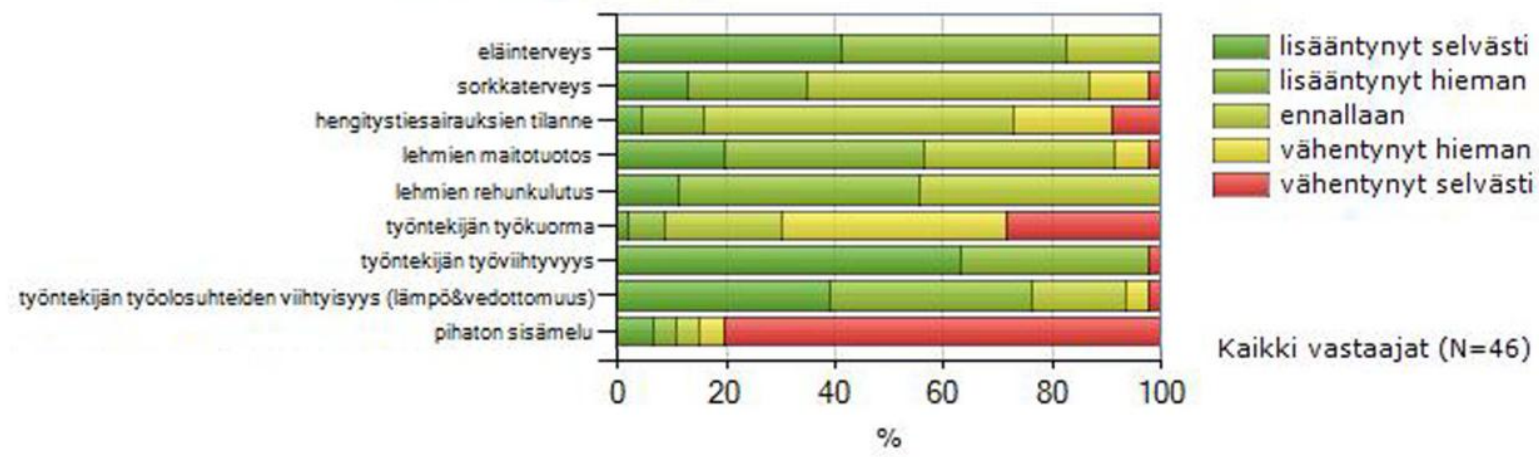

Kuva 5. Listaus muuttuneista olosuhteista suhteessa aikaisempaan kotieläinrakennukseen.

Lopuksi vastaajilta kysyttiin heidän yleistä tyytyväisyyttä valittuun ilmanvaihtoratkaisuun ja sen toimivuuteen. 97,8 \% oli täysin tyytyväinen valintaansa, 2,17 \% ei osannut muodostaa mielipidettä, ja kukaan ei ollut tyytymätön.

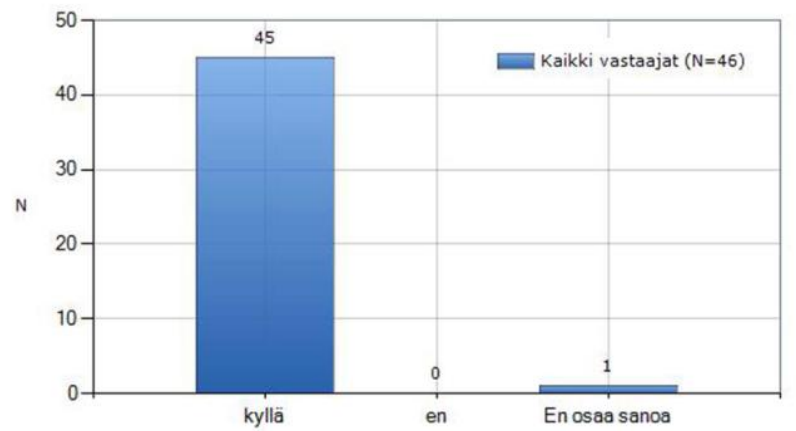

Kuva 6. Vastaajien tyytyväisyys valitsemaansa painovoimaiseen ilmanvaihtoratkaisuun

\section{Kirjallisuus}

KIVINEN, T. 2006. Verhoseinäisessä pihatossa ilma vaihtuu hyvin. Koetoiminta ja käytäntö 63, 3(16.10.2006): 3.

KIVINEN, T. 2006. Verhoseinäpihatto on nyt viileäpihatto. Teho 5: 15-18.

KIVINEN, T., MATTILA, K., TEYE, F., HEIKKINEN, J., HEIMONEN, I. 2006. Lämpöeristetyn verhoseinäisen lypsykarjapihaton ilmanvaihdon toimivuus. MTT:n selvityksiä 119: 63 s. Verkkojulkaisu päivitetty 15.11 .2006

KIVINEN, T. 2006. Tutkimuspihatoista hyvät tulokset : verhoseinä haastaa koneellisen ilmanvaihdon. Käytännön maamies 55, 14: 56-59. 